\title{
Picket Lines, Picket Fences: How Feminism Saved Iowa's Family Farms During the Farm Crisis of the 1980s
}

\section{Kenneth Dofner}

The stereotypical Iowa farm woman in the twentieth century stayed in the house, cooking and doing housework while the husband completed hard labor in the fields or barns. This stereotype also showed a woman who cared for the children on a daily basis and whose community involvement consisted of going to church and sharing social activities with other farm women. This image assumed that farm women were ignorant of feminist theory and activity and that the farm wife was not receptive to the concept of equality for women everywhere. Contrary to this stereotype, research supports the consistent action by many feminists in the 1980s with interests in both agriculture and rural women, especially in a state like Iowa that depended heavily on the agricultural sector for its economic output.

During the tumultuous 1960s in the United States, activism among the masses reached its peak in order to achieve equal rights for African-Americans and end the Vietnam War. This activist spirit also embodied the growing women's liberation movement that struggled to achieve equality for women in the 1970s, but later achieved great strides for the empowerment of women across the United States. As the second-wave feminist movement of the 1960s and 1970s slowly faded into a relic of American history, some feminists focused the message of equality and social justice on a new mission: to save the family farms of Iowa during the farm crisis of the 1980s. The political, social, and economic measures taken by feminists in the late 1970s and the 1980s assisted farmers and challenged the perception of the "masculinity" of farming during

Colloquium for History Majors (American): The US Women's Movement, 19601990. Instructor: Landon Storrs. The University of Iowa, Fall 2013. 
the worst agricultural crisis in the United States since the Great Depression of the 1930 s.

Feminism existed on family farms in Iowa during the first wave of feminism in the late $1^{\text {th }}$ century and early decades of the $20^{\text {th }}$ century. Some historians contend that "the history of the agrarian protest movements has periodically intersected with that of the organized women's movement."1 As women publicly strived to achieve the right to vote, the private labor of rural women proved essential to promoting feminism in order to achieve equality and independence from the male-dominated farming hierarchy in the growing expansion of American agriculture in the $20^{\text {th }}$ century. ${ }^{2}$ Later, when the Dust Bowl struck the Midwest in the 1930s and falling crop prices evicted families from their farms, rural Americans leaned on feminists like the famous First Lady Eleanor Roosevelt by viewing her as a "compassionate woman" who championed the rights of economic and social equality of "disadvantaged people." 3 The plight of the farmers in the Midwest, depicted in many famous photographs of the 1930s, provided a forum for feminists to continue their efforts to achieve equality for women caught up in this plight.

During the 1930s, a period of unrest on Iowa's farms, many rural advocacy groups arose from the droughts and depression with the mission to protect the interests of farm families by petitioning the government agencies to improve the national state of agriculture and offering new forums for vocal protest through services such as the Farm Bureau. Although the mainstream Farm Bureau had female members and a separate branch for women, some progressives viewed this as a politically correct appeasement by conservatives. In response, liberal rural citizens formed the liberally-leaning Farmers' Union, which integrated women into the fold and provided a forum for rural women in public policy. ${ }^{4}$ These actions for advocacy, regardless of political affiliation, continued the feminist tenets of social justice and class equality that proved effective in the second wave of feminism later in $20^{\text {th }}$ century America.

${ }^{1}$ Louise I. Carbert, Agrarian Feminism: The Politics of Ontario Farm Women (Toronto: University of Toronto Press, 1995), 5

${ }^{2}$ Mary Neth, Preserving the Family Farm: Women, Community, and the Foundations of Agribusiness in the Midwest, 1900-1940 (Baltimore: The Johns Hopkins University Press, 1995), 214.

${ }^{3}$ Katherine Jellison, Entitled to Power: Farm Women and Technology, 1913-1963 (Chapel Hill: The University of North Carolina Press, 1993), 74.

${ }^{4}$ Ibid, 78. 
Concern for America's farmers existed long before the Great Depression, as evident in the Progressive Era when Theodore Roosevelt established the Commission on Country Life. The U.S. government's interests in the family farm proved economically vital as the nation expanded its agricultural output with the technology introduced during the Industrial Revolution. However, farm women's initial resistance to feminism created a perception of ignorance from "the dominance of bourgeois, urban suffragists" who failed to understand the difficulty of rural feminists struggling for equality in their own environment. ${ }^{5}$ The perception of this ignorance perpetuated throughout the $20^{\text {th }}$ century and continues to exist for those unaware of the true cooperative nature of agriculture in Iowa.

For progressive feminists, the approval of the 19 1 th Amendment in 1920 legalized the right to vote for women, yet feminist activists maintained their concern for social justice by focusing on labor and economic issues. Farm women later created periodicals such as Farmer's Wife, which initially attracted a large audience that "actively supported the women's movement and the country life movement" and projected the image of the independent, feminist woman who was capable of managing the operations of a farm. ${ }^{6}$ Furthermore, the Farm Labor Program and the Women's Land Army provided outlets for feminists to promote the advancement of technology to increase the productivity of family farms in the midst of World War II. ${ }^{7}$ After women began to increase in numbers at the voting booths, they began to serve in community organizations, activist groups, and government positions on the local, state, and federal levels in order to further the New Deal programs that sought to protect families trying to maintain possession of their farms. With voting rights assured for women in 1920, feminists from both rural and urban backgrounds focused on the procurement of prosperity and equality for farmers while continuing feminist theory and practice, including shining a light on the labor and importance of women on the family farms of Iowa.

As the women's liberation movement gathered strength in the 1960s throughout the United States, agriculture also thrived in the 1960s and early 1970s to correct the failures of farming during the Great Depression. For example, the large-scale wheat sale to the Soviet Union in 1972 displayed a sign of optimism for the prosperity of family farms in the Midwest, including Iowa

${ }^{5}$ Carbert, Agrarian Feminism, 11.

${ }^{6}$ Neth, Preserving the Family Farm, 229.

${ }^{7}$ Jellison, Entitled to Power, 131-132. 
farmers that saw an increase in land price and a decrease of the price of agricultural commodities. ${ }^{8}$ The agricultural sector began to expand significantly in Iowa as farmers purchased greater amounts of farmland due to low interest rates. The introduction of new technology and farming practices, such as advances in irrigation techniques and new pesticides and machinery, further enabled local farmers to increase the production of grains and livestock.

However, this surge in new American family farms proved short-lived as the economic and political future of the United States became uncertain. The family farms of Iowa faced a potential downfall with the increase in interest rates, the evaporation of foreign markets for crops and livestock, the increase of rural Iowans migrating to urban areas in order to secure financial stability, and the government policies that favored large-scale agrarian operations for greater efficiency. With these perceived violations of justice for the common farmer, feminists who previously supported the women's liberation movement later served in positions of responsibility that later affected the political and socioeconomic landscape of Iowa.

The sociological aftermath of the farm crisis in Iowa affected farm families in various degrees, ranging from minor acts of depression to domestic violence. In one extreme case, the loss of farmland and livelihood led Dale Burr of Lone Tree, Iowa, to murder his wife, a banker, and a neighbor before committing suicide. ${ }^{9}$ This sense of hopelessness spread throughout the state of Iowa with increasing farm foreclosures, crime rates, and suicides, leading to a rise in the interest of the mental health of rural farmers in Iowa. These issues existed during a time of social conservatism and reaffirmation of "family values" of the Reagan administration. Despite this family-based orientation, rural activists created the belief that "Reaganomics," the reduction of government spending and taxes, was the primary factor of the devastation of the farm crisis in Iowa. ${ }^{10}$

Activists displayed their disgust with the economic failure of Iowa's family farms through the methods that feminists consistently used in the women's

8 David Ostendorf, “Iowa's Rural Crisis of the 1980s: Of Devastation and Democracy," in Family Reunion: Essays on Iowa, ed. Thomas J. Morain (Ames: Iowa State University Press, 1995), 58.

${ }^{9}$ Ann Marie Lipinski, “A Farming Legacy Wiped Out: Fall From Prosperity Too Much for Iowan," Chicago Tribune, December 11, 1985, accessed November 12, 2013, http://articles.chicagotribune.com/1985-12-11/news/8503250563_1_forbesestimates-dale-burr-hills-bank.

${ }^{10}$ Ostendorf, "Iowa's Rural Crisis of the 1980s," 63. 
liberation movement in the 1970s, such as the protests against failed farm policies in Des Moines and Washington, D.C., and white crosses planted to signify the loss of each farm during the crisis. Social workers concluded that "women rural activists have been found to be more effective" because their traditional "roles as mothers and female farmers" allowed them to display a first-hand narrative of the hardship that they experienced in the 1980s. ${ }^{11}$ The exposure of the sociological devastation of Iowa farmers allowed feminist activists to direct the public attention to the difficulties that laid ahead for the family farms.

The importance of social effects from the farm crisis highlighted the actions of both rural feminists from the farms of Iowa and urban feminists with an East Coast background and education that is often associated with secondwave feminism. Joan Blundall, a native of Philadelphia and an alumna of Temple University, furthered the work of the Northwest Iowa Mental Health Center in Sioux City by focusing on families affected by the farm crisis. She concluded that "voices, particularly those of women," helped publicize "the chronic economic, social, and emotional decline that exists in many parts of rural America" and assisted farmers with the treatment of the depression and anger they faced. ${ }^{12}$ Blundall's feminist promotion of rural women supported her social work and theories in northwest Iowa with the belief that "political solutions tend to divide people, shared sorrow brings people together." 13 Her creation of support groups in the local communities scattered across the rugged landscape of Iowa inspired women to take action and support activities that were "bigger and more important" than themselves. ${ }^{14}$ Iowa farmers typically adopted the masculine attitude of not sharing emotional issues with anyone, especially outsiders to rural Iowa. In spite of the initial hesitation, Blundall

${ }^{11}$ Julia Kleinschmidt Rembert, "Factors Affecting Iowa and Nebraska Farm Women's Rural and Farm Advocacy Involvement" (M.S.W. diss., University of Iowa, 1997), 3.

12 Blundall wrote an article "Lives of Courage, Legacies of Love" in the spring 1989 edition of Earth Matters, detailing her work in northwest Iowa.

13 An unpublished article by Blundall entitled "Support Groups and the Rural Crisis," Box 1, Joan Blundall papers, Iowa Women's Archives, The University of Iowa Libraries, Iowa City.

${ }^{14}$ Unknown author, "Joan Blundall: A Woman for All Seasons," The Dickinson County News, June 3, 2000, Box 1, Joan Blundall papers, Iowa Women's Archives, The University of Iowa Libraries, Iowa City. 
achieved success in curbing depression and anger in farmers who felt lost in a time of despair, a service that she continues into the $21^{\text {st }}$ century.

Meanwhile, also in the Sioux City area, Marilyn Murphy, an Iowa farm wife and mother, made the plight of the Iowa farmer more visible in the local newspapers through her activism in the charity wing of the Catholic Church. Religious activists and organizations shared the same motivation for equal rights and social justice as the feminist movement and protests of the farm crisis in the 1980s. This shared advocacy was further defined by Murphy's observation of the "dramatic decline of family farms." 15 Murphy's background as an Iowan woman solidified her arguments by showing the continuing conquest of the family farm structure in Iowa by large corporations looking to expand their agrarian operations. Furthermore, Murphy, whose social activism began in her fifties, used the theology of her Catholic faith to support her efforts for the passage of the Equal Rights Amendment and to spread her message of peace. Many religious figures, such as David Ostendorf of the United Church of Christ, organized the protests about the farm crisis in Iowa and, like Murphy and Ostendorf, shared a common interest in equality for both women and local farmers in Iowa. The importance of religious activists, which embodied a large number of social causes and movements, translated between the need to assist the disenfranchised farmer and the woman seeking equality in the United States.

Feminists who achieved success in the women's liberation movement in the Midwest not only embodied the ideal of community in their rural activism, but also confronted economic problems and created solutions to benefit family farms all across Iowa. Iowa's economic recession foreshadowed the farm crisis in the 1980s, which resulted in families losing their farms, crop prices falling to all-time lows, and businesses in small towns closing their doors. As the Iowa General Assembly and the U.S. Congress created committees to investigate the causes and effects of the farm crisis, feminists inspired a large number of rural women to be active in community and political activism. Dorothy Wurster of Ringgold County described her own experiences on her cattle farm to the Senate Agricultural Committee, painting a picture of pessimism for small

15 Pamphlet from the People's Initiative, Box 1, Marilyn Murphy papers, Iowa Women's Archives, The University of Iowa Libraries, Iowa City. 
businesses and rural farms in southwest Iowa. ${ }^{16}$ Wurster believed that if "every five or six farmers...go out of business, one store on Main Street folds." 17 Many towns that were a great distance from the urban centers of Iowa, such as Des Moines, Davenport, and Sioux City, relied heavily on the local businesses that supplied necessities for both the home and the fields of family farmers. These rural towns and businesses sought the help of feminists like Wurster by continuing their involvement with the local farms and businesses that she testified about and maintaining visibility on the difficulties experienced in rural Iowa.

Other activists who promoted economic cures for the farm crisis gained experience not only in the feminist movement of the 1970s, but also in the protests against the Vietnam War in the late 1960s. In Atlantic, Iowa, Denise O'Brien became active in progressive politics in southwest Iowa and served in various community organizations in order to help farmers address economic issues that arose from the farm crisis. O'Brien received a practical education in social protests through her work in anti-war, women's liberation, and organic food movements in San Francisco. She continued her work in Iowa by chairing a citizen's panel during the Democratic Party's presidential debates in 1984, testifying at a Democratic National Committee platform hearing in Illinois, and moderating a forum between Cass County farmers and Iowa Governor Terry Branstad. ${ }^{18}$

O'Brien focused on one issue that concerned both feminists and rural women alike: the equal pay of women in the workplace. As the farm crisis depleted the savings of Iowa farmers, many rural women obtained off-the-field employment, only to discover the vast wage difference between men and women. Due to the lack of economic diversity in many rural areas of Iowa, women received $44 \%$ of the typical male salary in Iowa, substantially worse than the national average of female-to-male ratio of 62 cents on the male dollar. ${ }^{19}$ O’Brien, among many other rural feminists, fought to achieve economic equality for rural Iowans by seeking an extension of the foreclosure

${ }^{16}$ U.S. Senate Agricultural Committee Testimony, February 10, 1987, Box 1, Dorothy Fox Wurster papers, Iowa Women's Archives, The University of Iowa Libraries, Iowa City.

${ }^{17}$ Idem.

${ }^{18}$ Denise O’Brien papers, Iowa Women's Archives, The University of Iowa Libraries, Iowa City.

19 Box 16, Denise O’Brien papers, Iowa Women's Archives, The University of Iowa Libraries, Iowa City. 
redemption period to five years in 1985 and debt reduction in both principal and interest on farm loans by at least 33\% ${ }^{20}$ In the midst of the farm crisis that displaced many farmers, O’Brien furthered the progressive nature of feminism to assist these farmers while fighting for the equality of women in the workplace.

The increase in women serving in Des Moines and local offices in Iowa's counties confirmed the impact of second-wave feminism in a progressively agrarian state like Iowa. The overall despair of the farm crisis in Iowa captured the attention of politicians, community leaders, and activists to re-evaluate the control of agriculture on the local, state, and federal government levels. In Washington, D.C., Congress investigated the legal practices of agencies like the Farm Credit System and Farmers Home Administration as the increase of foreclosed family farms created a panic among Iowa's farmers. On the state and local levels of Iowa's government, rural feminists like Josephine Gruhn of Dickinson County brought first-hand experience and knowledge to the political arena in order to translate effectively with the disenfranchised farmers.

Gruhn's election to the Iowa House of Representatives in 1982 signaled the acceptance of feminism on a political level, especially in light of her status as a Democrat in a predominantly Republican region of Iowa. As vice-chair of the Agriculture Committee in the Iowa House, Gruhn furthered the agenda of relief of "the plight of the financially strapped farmer" by using her previous experience as a county treasurer and involvement in the American Association of University Women and the Northwest Iowa Farm Business Association. ${ }^{21}$ In addition, her support of agricultural legislation from both the Iowa House and Senate funded programs to assist farmers in obtaining low-interest farm loans and expanding markets for Iowa's crops and livestock. ${ }^{22}$ After her retirement in 1992, her impact on rural Iowa was summarized in a simple statement when she started her legislative career, stating that "a woman...can do just as good a job as a man." ${ }^{23}$ Her quiet, low-key nature resonated feminist

${ }^{20}$ Box 18, Denise O’Brien papers, Iowa Women's Archives, The University of Iowa Libraries, Iowa City.

${ }^{21}$ Spencer, IA panel discussion, March 5, 1983, Box 1, Josephine Gruhn papers, Iowa Women's Archives, The University of Iowa Libraries, Iowa City.

22 "Capitol Points" news releases, Box 2, Josephine Gruhn papers, Iowa Women's Archives, The University of Iowa Libraries, Iowa City.

23 This quote was from a letter to Gruhn's campaign advisor Stephanie Heitman, Box 1, Josephine Gruhn papers, Iowa Women's Archives, The University of Iowa Libraries, Iowa City. 
ideals through her work of promoting equal rights for women in maledominated institutions and setting the example for future rural feminists to work in roles of government and community activism.

The political ramifications of second-wave feminism in Iowa existed not only in the chambers of the Iowa General Assembly, but through grassroots organizations that sought to change the government's agricultural policies. One such organization, the North American Farm Alliance (NAFA), was cofounded by Carol Hodne in 1983, who experienced activism from an early age through her parents. Hodne participated in protests against the Vietnam War and supported the women's liberation movement during her education at Iowa State University. Her interest in feminism allowed her to help establish the women's studies program at Iowa State and later supported the Ames Feminist Women's Health Center to assist women in need. ${ }^{24}$

After the farm crisis began to take effect in Iowa, Hodne, who previously worked with the U.S. Farmers Association and the Farmers' Union, relied on her experience and her "socialist, feminist rhetoric and analysis" to support Congressional legislation that centered on Iowa farmers. ${ }^{25}$ The NAFA also continued their populist message under Hodne's leadership through their publication North American Farmer, a periodical that supported the "women's strategic role in the farm movement." 26 The NAFA's popularity with Iowa rural farmers was the passage of the Save the Family Farm Act in 1985, which was written in part by Senator Tom Harkin in the U.S. Congress. Carol Hodne's background differed from many Iowans raised on the family farm tradition, yet her support of feminist and socialist ideals supported Iowa farmers in their fight against the causes of the farm crisis.

The feminist movement of the 1970s also affected Jo Ann Zimmerman, another advocate for the fight against the farm crisis in Iowa. Raised in the rolling hills of Van Buren County, Zimmerman understood the perception surrounding the ambiguity of female labor on the farm and following a

${ }^{24}$ Ames Feminist Women's Health Center pamphlet, Box 1, Carol Hodne papers, Iowa Women's Archives, The University of Iowa Libraries, Iowa City.

${ }^{25}$ Box 1, Carol Hodne papers, Iowa Women's Archives, The University of Iowa Libraries, Iowa City.

${ }^{26}$ Box 2, Carol Hodne papers, Iowa Women's Archives, The University of Iowa Libraries, Iowa City. 
traditional path for women in Iowa by becoming a nurse. ${ }^{27}$ In the 1960 s, however, the vast increase of women enrolled in higher education included Zimmerman's enrollment at Iowa State University. After her election in 1982 to the Iowa House of Representatives, Zimmerman paved the way for future women legislators to work for Iowa on both the state and federal levels. Her election was considered a rare occasion in the early 1980 s, as only $9.4 \%$ of the elected officials in the United States were women. ${ }^{28}$ In 1986, Zimmerman surprised many pundits by becoming the first female Lieutenant Governor in Iowa's history. Due to her new post, she became the President of the Iowa Senate, sitting at the intersection of the legislative and executive functions of the state government. ${ }^{29}$

In the midst of her campaign for the Lieutenant Governor seat, her personal life faced the same hardships as many Iowa farmers when the Farmers Home Administration threatened foreclosure of her family's cattle farm near Waukee, Iowa in 1987.30 Zimmerman subsequently focused on the health and economic status of Iowa's farmers by supporting the Senate Bill 2092, which allotted $\$ 4.65$ million to assist the expansion of Iowa's pastures, and funding for emergency medical services that was previously unavailable in rural Iowa. ${ }^{31}$ The longtime feminist later supported Iowa's effort to ratify a state version of the Equal Rights Amendment and inspired Iowa's young women to "speak up and stop being sacrificial lambs in order to succeed in politics." 32 Her vital position as Lieutenant Governor provided the opportunity for Zimmerman to address issues for both feminists and rural farmers to obtain equal rights for those affected by the farm crisis in Iowa.

${ }^{27}$ Box 1, Jo Ann Zimmerman papers, Iowa Women's Archives, The University of Iowa Libraries, Iowa City.

${ }^{28}$ March 1983 memo, Rutgers University's Center for American Women and Politics, Box 4, Jo Ann Zimmerman papers, Iowa Women's Archives, The University of Iowa Libraries, Iowa City. In 1987, 15.7\% of elected officials were women.

${ }^{29}$ Box 4, Jo Ann Zimmerman papers, Iowa Women's Archives, The University of Iowa Libraries, Iowa City

${ }^{30}$ Mary Hargrove, "She Won the Election But May Lose a Farm," April 20, 1987, Box 5, Jo Ann Zimmerman papers, Iowa Women's Archives, The University of Iowa Libraries, Iowa City.

${ }^{31}$ Box 6, Jo Ann Zimmerman papers, Iowa Women's Archives, The University of Iowa Libraries, Iowa City.

${ }^{32}$ Unknown author, "A New Era for Women in Politics Forecasted," Knoxville JournalExpress, March 19, 1988, Box 5, Jo Ann Zimmerman papers, Iowa Women's Archives, The University of Iowa Libraries, Iowa City. 
The impact of the farm crisis of the 1980s has yet to be fully realized by both natives of Iowa and the rest of the country. Thirty years later, artifacts of the once-thriving family farm now projects its image of dilapidated barns and empty fields across the expansive Iowa landscape. Despite this result of the farm crisis, family farms across the state survived through the crisis by relying on the diversity and technology that have recently became the cornerstone of Iowa's socioeconomic identity. Credit for saving Iowa's family farms has often fallen to the leaders of the state during the farm crisis, such as Governor Terry Branstad and Senators Tom Harkin and Charles Grassley. However, credit also belonged with the activists who gained activist experience during the feminist movements in the 1960s and 1970s and relied on the message of social justice and equality that many feminists asserted throughout the women's liberation movement. Whether the activism occurred through the independent rural woman protesting government actions or through the politician struggling to change the traditional mindset that government had been accustomed to, feminist theory and action created a foundation to benefit the future of agriculture in Iowa with the hopeful intention of preventing another economic and social crisis.

\section{Bibliography}

\section{Primary Sources:}

Lipinski, Ann Marie. “A Farming Legacy Wiped Out: Fall From Prosperity Too Much for Iowan." Chicago Tribune, December 11, 1985. Accessed November 12, 2013. http://articles.chicagotribune.com/1985-12-11/news/8503250563_1_forbesestimates-dale-burr-hills-bank.

Joan Blundall papers. Iowa Women's Archives. The University of Iowa Libraries. Iowa City.

Josephine Gruhn papers. Iowa Women's Archives. The University of Iowa Libraries. Iowa City.

Carol Hodne papers. Iowa Women's Archives. The University of Iowa Libraries. Iowa City.

Marilyn Murphy papers. Iowa Women's Archives. The University of Iowa Libraries. Iowa City.

Denise O'Brien papers. Iowa Women's Archives. The University of Iowa Libraries. Iowa City.

Dorothy Wurster papers. Iowa Women's Archives. The University of Iowa Libraries. Iowa City. 
Jo Ann Zimmerman papers. Iowa Women's Archives. The University of Iowa Libraries. Iowa City.

\section{Secondary Sources:}

Carbert, Louise I. Agrarian Feminism: The Politics of Ontario Farm Women. Toronto: University of Toronto Press, 1995.

Jellison, Katherine. Entitled to Power: Farm Women and Technology, 1913-1963. Chapel Hill: The University of North Carolina Press, 1993.

Neth, Mary. Preserving the Family Farm: Women, Community, and the Foundations of Agribusiness in the Midwest, 1900-1940. Baltimore: The Johns Hopkins University Press, 1995.

Ostendorf, David. "Iowa's Rural Crisis of the 1980s: Of Devastation and Democracy." In Family Reunion: Essays on Iowa, edited by Thomas J. Morain, 54-71. Ames: Iowa State University Press, 1995.

Rembert, Julia Kleinschmidt. "Factors Affecting Iowa and Nebraska Farm Women's Rural and Farm Advocacy Involvement.” M.S.W. diss., University of Iowa, 1997. 